\title{
Modifikasi Ventilasi pada Tutup Stup Koloni Lebah Madu (Apis Mellifera) Terhadap Produksi Propolis
}

\section{Modified Ventilation on Hive Cover of Honey Bee toward Production of Propolis}

\author{
E. Ramadhan'), H. C. H. Siregar'), Kuntadi' ${ }^{2)}$ \\ ${ }^{1)}$ Fakultas Peternakan, InstitutPertanian Bogor \\ ${ }^{2)}$ Departemen Ilmu Produksidan Teknologi Peternakan, Fakultas Peternakan, Institut Pertanian Bogor, Jl. \\ Agatis, Kampus IPB Dramaga, Bogor 16680, Indonesia
}

\begin{abstract}
This research aims to determine the best ventilation modification to produce propolis. The study was conducted at the foot of Mount Tampomas, Sumedang, West Java, in 5 weeks from July to August 2013. The material used were 15 hives of Apis mellifera honey bee colony with population $16000-20000$ bees. The 15 colonies were randomly divided into 3 levels treatment of ventilation size on the lid nest, that were no ventilation as control treatment $(A), 50 \mathrm{~cm}^{2}(B)$, and $100 \mathrm{~cm}^{2}(C)$ ventilation holes. Propolis trap was installed in each hive. The experimental design used was completely randomized design followed by T-test. The results showed that ventilation size was not significantly affected propolis production but significantly affected honey production. Honey production in $\mathrm{C}$ treatment was significantly higher. In general the best treatment hive cap to produced propolis and honey are $\mathrm{C}$ treatment with the highest average weight of propolis and honey for 5 weeks was $16.4 \pm 6.98 \mathrm{~g}$ and $3101.6 \pm 581.5 \mathrm{~g}$ also have a big end population.
\end{abstract}

Keywords: Apis mellifera, propolis trap, propolis production, ventilation

\section{PENDAHULUAN}

Lebah madu $A$. mellifera merupakan jenis serangga yang sudah dibudidayakan secara luas di seluruh dunia, dan termasuk salah satu objek hewan yang banyak dipelajari dalam bidang peternakan. Beberapa hasil produk langsung dari lebah madu yang bernilai komersil yaitu madu, lilin lebah, pollen, royal jelly, dan propolis.

Dewasa ini muncul obat alternatif alami yang ramai dijadikan bisnis. Obat tersebut yaitu propolis yang diekstrak dari propolis mentah yang dihasilkan oleh lebah. Propolis merupakan salah satu produk lebah madu yang bernilai ekonomi tinggi. Nilai jual propolis mentah saat ini mencapai Rp. 600 - 700.- ribu per kg (Budiaman dan Rahman 2006). Nilai jual propolis yang tinggi disebabkan karena keampuhan zat yang terkandung di dalamnya untuk mengobati berbagai penyakit, khususnya yang berhubungan dengan infeksi (Radiati 2001). Bahkan, di Brazil propolis telah digunakan untuk pengobatan penyakit kanker (daSilva et al. 2004).

Propolis adalah bahan perekat atau dempul yang berasal dari resin tumbuhan yang dikumpulkan oleh lebah pekerja dari kuncup, kulit batang, atau bagian-bagian lain tumbuhan (Anggraini 2006). Propolis digunakan sebagai penutup celah stup atau lubang-lubang kecil di dinding ruangan yang terdapat sarang lebah di dalamnya (Pavord 1970; Free 1982) sebagai upaya perlindungan diri alami dari musuh, terutama bakteri dan virus.

Perkembangan teknologi terkait peningkatan produksi propolis saat ini belum mendapatkan solusi yang memuaskan, khususnya bagi peternak lebah madu di Indonesia. Fiberglass merupakan bahan terbaik untuk perangkap propolis (propolis trap). Penempatan perangkap propolis yang paling baik pada stup yaitu searah dengan sisiran lebah (Budiaman dan Rahman 2006). Cara lain untuk meningkatkan produksi propolis dilakukan oleh peternak lebah Hungaria dengan memberi ventilasi pada stup lebah, namun belum diketahui luas optimum untuk produksi propolis maksimal (Pcelovodstvo Magazine 2012).

Produksi propolis dipengaruhi banyak faktor seperti jenis lebah, kondisi iklim dan geografis, jenis stup, ketersediaan sumber propolis di alam dan kekuatan koloni lebah (Pcelovodstvo Magazine 2012). Temperatur juga menjadi salah satu faktor yang memengaruhi produksi propolis. Iannuzzi (1983) menyatakan bahwa propolis terdeposit pada perangkap propolis lebih banyak ketika suhu dalam stup menjadi dingin. Lebah madu menggunakan propolis untuk menutup dan memperbaiki dinding stup yang rusak untuk melindungi sarang dari cekaman suhu lingkungan. Hal ini mendorong munculnya ide untuk mengondisikan stup agar dalam kondisi bersuhu rendah melalui modifikasi ventilasi pada tutup stup sehingga dapat memaksa lebah pekerja A. Mellifera mencari propolis. Penelitian ini bertujuan untuk mengetahui pengaruh modifikasi ventilasi pada tutup stup koloni lebah terhadap jumlah propolis dan madu yang dihasilkan oleh lebah $A$. mellifera dan memilih perlakuan terbaik dalam menghasilkan propolis dan madu. 


\section{MATERI DAN METODE}

\section{Waktu dan Tempat Penelitian}

Penelitian berlangsung selama $5 \mathrm{minggu}$, dari bulan Juli - Agustus 2013 dan dilaksanakan di Desa Licin, Kecamatan Cimalaka, Kabupaten Sumedang, Jawa Barat. Desa Licin adalah salah satu lokasi penggembalaan lebah madu dengan sumber pakan lebah yang dominan yaitu tanaman kaliandra (Calliandra calothyrsus).

\section{Bahan}

Bahan utama penelitian adalah 15 koloni lebah $A$. mellifera yang terdiri dari 8 sisiran madu tiap stup. Setiap stup lebah berisi sekitar 16000 - 20000 ekor lebah. Bahanbahan lainnya yaitu perangkap propolis (propolis trap) plastik dan tutup stup dari papan kayu dengan modifikasi ventilasi.

\section{Alat}

Alat-alat yang digunakan antara lain timbangan digital tipe SCA-301, termohigrometer merek Mashtech MS6503, anemometer merek Mastech MS 6250, luxmeter merek Hanna HI97500, pakaian pelindung dari sengatan lebah, timbangan digital $100 \mathrm{~g}$ merek Acis, dan timbangan koloni kapasitas $20 \mathrm{~kg}$ merek CAS SW-1.

\section{Prosedur \\ Rancangan Percobaan}

Rancangan acak lengkap (RAL) digunakan sebagai rancangan penelitian dengan perlakuan berupa modifikasi ventilasi pada tutup stup yang terdiri dari 3 taraf, $\operatorname{taraf} \mathrm{A}($ kontrol $\left.)=0 \mathrm{~cm}^{2}, \mathrm{~B}[2(5 \times 1)+2(20 \times 1) \mathrm{cm})\right]=50 \mathrm{~cm}^{2}$, dan $\mathrm{C}[2(10 \mathrm{x} 1)+2(40 \mathrm{x} 1) \mathrm{cm})]=100 \mathrm{~cm}^{2}$. Masing-masing taraf perlakuan terdiri dari 5 ulangan. Model matematika yang digunakan (Mattjik dan Sumertajaya 2002) adalah:

$$
\mathrm{Yij}=\mu+\mathrm{Pi}+\varepsilon_{\mathrm{ij}}
$$

Keterangan:

Yij : pengamatan pada perlakuan ke- i dan ulangan ke- j;

$\mu$ : rataan umum;

Pi : pengaruh perlakuan ke- i;

Eij : pengaruh acak pada perlakuan ke- i ulangan ke- j.

\section{Peubah yang Diamati}

Peubah yang diamati adalah produksi propolis dan madu dan perkembangan populasi koloni. Kondisi suhu dan kelembaban di luar dan di dalam stup juga diamati sebagai data pendukung.

\section{Modifikasi Tutup Stup}

Ke 15 stup secara acak dibagi menjadi 3 kelompok ventilasi ( $\mathrm{A}, \mathrm{B}$, dan $\mathrm{C}$ ) yang masing-masing terdiri dari 5 buah stup dan kemudian diberi label sesuai perlakuan.

Penimbangan Bobot Awal Perangkap Propolis

Penimbangan awal perangkap propolis dilakukan sebelum dipasang dimasing-masing stup. Hasil bobot awal perangkap propolis dicatat dan menjadi acuan setiap penambahan bobot propolis yang terdapat pada perangkap tersebut. Setiap alat perangkap propolis diberi label dan dipasang pada stup yang telah ditentukan sesuai jenis perlakuan.

\section{Kondisi Lingkungan}

\section{Tahap Pengumpulan Data}

Kondisi lingkungan adalah kondisi suhu, kelembaban, intensitas cahaya, dan kecepatan angin di lokasi penelitian. Pengukuran suhu dan kelembaban di dalam kotak dilakukan di antara tutup stup dan sisiran lebah. Pengukuran intensitas cahaya dilakukan pada bagian depan pintu masuk stup lebah. Pengukuran kecepatan angin dilakukan pada wilayah sekitar stup lebah ditempatkan. Pengukuran dilakukan pada pagi hari pukul 07.00, siang hari pukul 12.00 dan sore hari pukul 17.00 selama 5 minggu.

2. Produksi Propolis

Produksi propolis adalah bobot propolis yang dambil dari perangkap propolis seminggu sekali selama 5 minggu dengan menimbang propolis yang dihasilkan oleh setiap koloni. Bobot propolis dihitung menggunakan rumus sebagai berikut :

$$
\mathrm{A}=\mathrm{B}-\mathrm{C}
$$

Keterangan :

$\mathrm{A}=$ bobot propolis $(\mathrm{g})$

$\mathrm{B}=$ bobot propolis trap + bobot propolis

$\mathrm{C}=$ bobot propolis trap

\section{Produksi Madu}

Produksi madu dihasilkan pada tiap koloni selama 5 minggu. Pengukuran produksi madu diperoleh dari selisih antara bobot sisiran berisi madu dengan bobot sisiran kosong setelah diekstraksi. Perhitungan bobot madu menggunakan rumus:

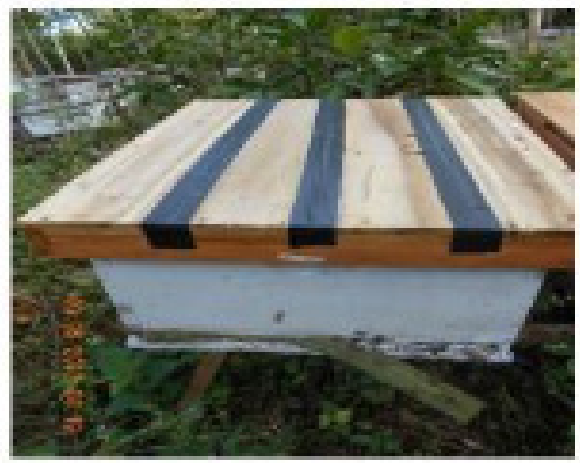

A (ventilasi $0 \mathrm{~cm}^{2}$ )

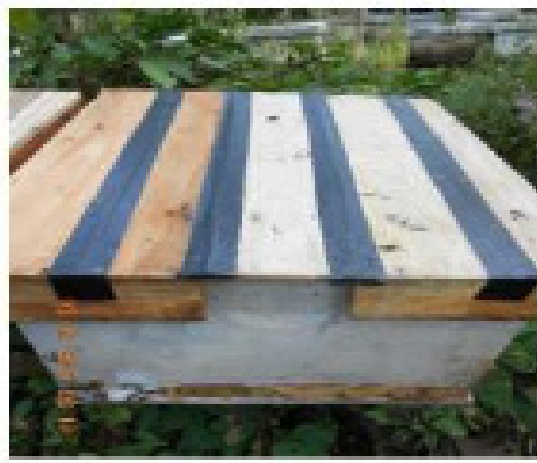

B (ventilasi $50 \mathrm{~cm}^{2}$ )

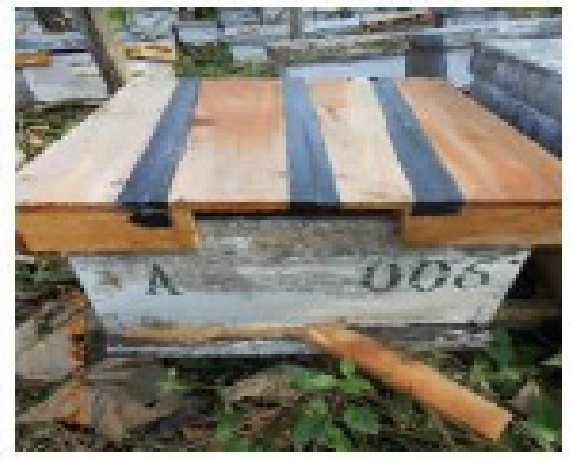

C (ventilasi $100 \mathrm{~cm}^{2}$ )

Gambar 1 Hasil amplifikasi gen POU1F1 pada gel agarose 1,5\% 
Bobot madu $=($ Bobot sisiran isi madu - Bobot sisiran kosong)

4. Populasi Lebah

Populasi lebah adalah jumlah lebah dalam 1 koloni yang diperoleh dari hasil bagi antara bobot koloni dan bobot rata-rata per ekor lebah. Penimbangan dilakukan di awal dan akhir penelitian saat awal minggu pertama dan akhir minggu kelima.

Bobot koloni $=($ Bobot lebah + Bingkai sarang $)-$ Bingkai
sarang

Bobot koloni

Populasi koloni $=\frac{\text { Bobot rata-rata per-ekor lebah pekerja }}{\text { Bob }}$

\section{Analisis Data}

Data bobot propolis, madu, dan jumlah populasi akhir dianalisis ragam (ANOVA). Perlakuan yang berpengaruh nyata terhadap peubah yang diamati diuji lebih lanjut dengan uji Tukey untuk mengetahui perbedaan diantara perlakuan tersebut.

\section{HASIL DAN PEMBAHASAN}

\section{Sumber Pakan}

\section{Kondisi Wilayah Penelitian}

Sumber pakan lebah yang terdapat di lokasi penelitian adalah dominan tanaman kaliandra (Calliandra calothyrsus). Tanaman ini memberikan nektar yang melimpah bagi lebah untuk dijadikan sebagai madu (Husaeni 1986). Tanaman ini kurang menghasilkan pollen sebagai kebutuhan pokok dalam memelihara keberlangsungan hidup anakan lebah untuk regenerasi koloni. Selain tanaman kaliandra juga terdapat tanaman pinus (Pinus mercusii) sebagai sumber penghasil resin (propolis) yang kemudian dikumpulkan oleh lebah (Singh 1962).

Temperatur, Kelembaban, Intensitas Cahaya, dan Kecepatan Angin

Hasil pengukuran faktor fisik kondisi lingkungan pembudidayaan lebah di Desa Licin, Kecamatan Cimalaka, Kabupaten Sumedang, ditampilkan pada Tabel 1. Kondisi lingkungan di lokasi penelitian dalam Tabel 1 di atas masih cukup nyaman bagi aktifitas lebah madu. Menurut Yani dan Purwanto (2006) ternak membutuhkan lingkungan yang cocok untuk mempertahankan hidup, pertumbuhan, dan produksi maksimal serta kebutuhan fisiologisnya. Menurut Rochim et al. (2013), perkembangan anakan lebah madu menjadi optimal pada kondisi suhu berkisar antara 34 $35{ }^{\circ} \mathrm{C}$. Suhu juga mempengaruhi jumlah propolis yang dikumpulkan oleh lebah pekerja. Kenaikan suhu membuat resin dan lilin dari tanaman menjadi lunak dan memudahkan
Tabel 2 Rataan bobot propolis dari koloni setiap perlakuan

\begin{tabular}{lcc}
\hline \multicolumn{1}{c}{ Perlakuan } & $\begin{array}{c}\text { Bobot rata-rata } \\
(\mathrm{g})\end{array}$ & $\begin{array}{c}\text { Koefisien } \\
\text { keragaman }(\%)\end{array}$ \\
\hline A (ventilasi $\left.0 \mathrm{~cm}^{2}\right)$ & $14,8 \pm 14,65$ & 99 \\
$\mathrm{~B}\left(\right.$ ventilasi $\left.50 \mathrm{~cm}^{2}\right)$ & $16,4 \pm 6,98$ & 42,6 \\
$\mathrm{C}\left(\right.$ ventilasi $\left.100 \mathrm{~cm}^{2}\right)$ & $14,0 \pm 5,29$ & 37,8 \\
\hline Rataan Umum & 15,06 & \\
\hline
\end{tabular}

lebah untuk memprosesnya (Jager 2001).

Kelembaban udara pada Tabel 1 berkisar antara $57 \%$ - 99\%. Kelembaban dalam kisaran tersebut masih cukup nyaman bagi kehidupan lebah karena lebah dapat beraktivitas optimal pada kelembaban 48\% - 98\% (Junior et al. 2010). Intensitas cahaya pun turut berpengaruh terhadap aktifitas terbang lebah. Menurut Hilario et al. (2000), lebah mulai terbang di intensitas cahaya rendah dan lebih banyak lagi ketika intensitas cahaya melampaui 2 (klx). Kecepatan angin di lokasi penelitian berkisar 1,45 $\mathrm{m} \mathrm{detik}^{-1}$. Kecepatan ini masih tergolong rendah dan baik karena mendukung aktifitas lebah. Menurut Pusat Perlebahan Apiari Pramuka (2005), habitat yang baik bagi kehidupan lebah adalah tidak terdapat angin kencang.

\section{Produksi Propolis}

Rataan produksi propolis setiap perlakuan selama 5 minggu berkisar antara $14.0 \mathrm{~g}$ sampai $16,8 \mathrm{~g}$ atau 3,76 g setiap 10 hari (Tabel 2). Hasil ini hampir 2 kali lipat dari yang dihasilkan oleh penelitian sebelumnya yaitu Budiaman dan Rahman (2006) dengan stup tanpa modifikasi ventilasi sebesar 2,03 g setiap 10 hari. Data produksi propolis memenuhi uji asumsi, baik uji kenormalan maupun uji kehomogenan. Hasil ANOVA memperlihatkan bahwa rataan bobot propolis ketiga perlakuan tidak berbeda nyata dengan rataan bobot produksi sebesar 15,06 g per 5 minggu (Tabel 2).

Pertambahan bobot propolis setiap minggu tercantum dalam Gambar 2 yang memperlihatkan bahwa perlakuan B memiliki keunggulan, yakni telah menunjukkan produksi propolis yang lebih tinggi dari kedua perlakuan lainnya sejak minggu kedua sampai minggu keempat. Salah satu faktor yang mempengaruhi produksi propolis adalah temperatur dalam sarang. Menurut de Lima (2005), produksi propolis $A$. mellifera dipengaruhi oleh temperatur dalam stup dan intensitas cahaya matahari. Selain itu, produksi propolis juga dipengaruhi oleh kelimpahan dan keragaman jenis tumbuhan sekitar peternakan lebah, jenis lebah, jumlah koloni, iklim, curah hujan, dan cuaca. Produksi propolis akan tinggi jika suhu dalam menjadi dingin (Iannuzzi 1983). Salah satu strategi yang digunakan oleh lebah adalah dengan menutup celah-celah pada tutup stup.

Tabel 3 memperlihatkan kondisi temperatur di

Tabel 1 Rataan suhu, kelembaban, intensitas cahaya, dan kecepatan angin di lokasi penelitian

\begin{tabular}{|c|c|c|c|}
\hline Parameter & Pagi (07.00) & Siang (12.00) & Sore $(17.00)$ \\
\hline Suhu lingkungan ${ }^{\circ} \mathrm{C}$ & $21,04 \pm 1,25$ & $31,60 \pm 1,14$ & $26,9 \pm 1,03$ \\
\hline Kelembaban (\%) & $99,50 \pm 0,79$ & $57,10 \pm 5,4$ & $77,5 \pm 8,2$ \\
\hline Intensitas cahaya ( Klx ) & $0,70 \pm 0,29$ & $5,54 \pm 0,79$ & $0,86 \pm 0,33$ \\
\hline Kecepatan angin ms-1 & 0 & $1,45 \pm 0,54$ & 0 \\
\hline
\end{tabular}


Tabel 3 Rataan suhu dalam stup koloni lebah madu setiap perlakuan

\begin{tabular}{lcccc}
\hline & Perlakuan & \multicolumn{3}{c}{ Suhu ${ }^{\circ} \mathrm{C}$} \\
\cline { 3 - 5 } & & Pagi (07.00) & Siang (12.00) & Sore $(17.00)$ \\
\hline $\mathrm{A}\left(\right.$ ventilasi $\left.0 \mathrm{~cm}^{2}\right)$ & & $23,14 \pm 2,85$ & $35,32 \pm 1,25$ & $27,64 \pm 0,97$ \\
$\mathrm{~B}\left(\right.$ ventilasi $\left.50 \mathrm{~cm}^{2}\right)$ & & $23,00 \pm 2,94$ & $35,68 \pm 1,12$ & $27,56 \pm 0,98$ \\
$\mathrm{C}\left(\right.$ ventilasi $\left.100 \mathrm{~cm}^{2}\right)$ & & $22,90 \pm 2,99$ & $35,94 \pm 0,85$ & $28,14 \pm 1,59$ \\
\hline & Rataan & 23,01 & 35,64 & 27,78 \\
\hline
\end{tabular}

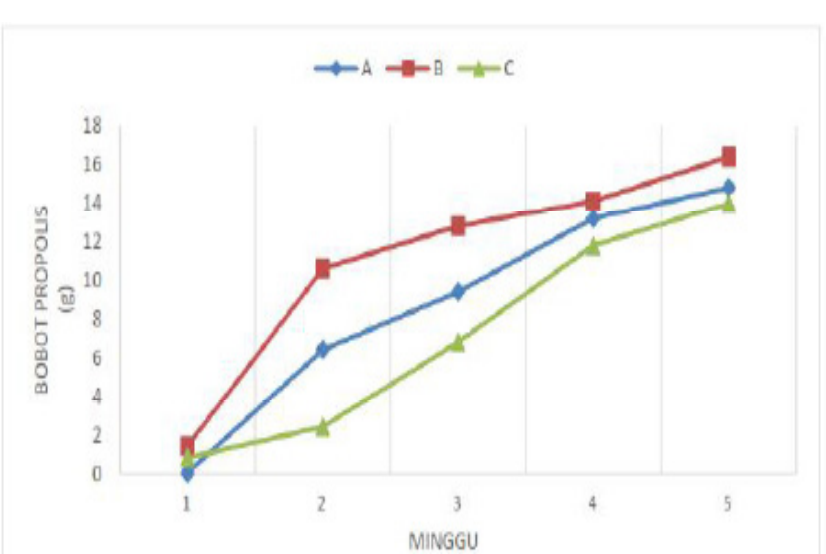

Gambar 2 Grafik rataan pertambahan bobot badan propolis setiap minggu, A (ventilasi $0 \mathrm{~cm}^{2}$ ), B (ventilasi $50 \mathrm{~cm}^{2}$ ), C (ventilasi $100 \mathrm{~cm}^{2}$ )

dalam stup pada pagi, siang, dan sore hari pada ketiga taraf perlakuan. Tabel 3 menunjukkan perbedaan yang tidak nyata antara perlakuan dengan suhu dalam stup. Perbedaan yang tidak nyata terhadap suhu dalam stup berakibat pada produksi propolis yang juga tidak berbeda nyata. Hasil penelitian ini juga didukung oleh Giselle et al. (2009) yang dalam penelitiannya secara umum tidak ditemukan korelasi yang positif antara suhu dan produksi propolis.

Hasil pembahasan di atas memperlihatkan bahwa faktor lingkungan seperti suhu dan kelembaban dalam penelitian ini tidak mempengaruhi produksi propolis (Tabel 5), selain itu faktor jumlah populasi lebah juga tidak memberikan pengaruh yang nyata terhadap koloni lebah $A$. Mellifera (Tabel 6). Dugaan sementara bahwa ada faktor lain yang mempengaruhi produksi propolis dalam koloni A. Mellifera yaitu kualitas ratu lebah. Menurut Junus (2011), kualitas ratu seperti umur sangat mempengaruhi kualitas lebah pekerja terhadap hasil produksi madu, polen, sisiran anakan hingga produk propolis. Umur ratu dalam penelitian ini memang tidak diseragamkan karena kurangnya informasi ketika awal penelitian dan juga tidak ada informasi yang tepat terkait umur ratu pada setiap stup dari peternak lebah.

Tabel 4 Rataan bobot madu dari koloni setiap perlakuan

\begin{tabular}{lcc}
\hline \multicolumn{1}{c}{ Perlakuan } & Bobot rata-rata $(\mathrm{g})$ & $\begin{array}{c}\text { Koefisien } \\
\text { keragaman }(\%)\end{array}$ \\
\hline A (ventilasi $\left.0 \mathrm{~cm}^{2}\right)$ & $3.836,2 \pm 945,5 \mathrm{a}$ & 24,6 \\
$\mathrm{~B}\left(\right.$ ventilasi $\left.50 \mathrm{~cm}^{2}\right)$ & $1.661,0 \pm 446,7 \mathrm{~b}$ & 26,9 \\
$\mathrm{C}\left(\right.$ ventilasi $\left.100 \mathrm{~cm}^{2}\right)$ & $3.101,6 \pm 581,5 \mathrm{a}$ & 18,7 \\
\hline
\end{tabular}

Keterangan : $a, b=$ angka yang disertai huruf berbeda pada kolom yang sama menunjukkan nilai yang berbeda nyata pada taraf $5 \%$

\section{Produksi Madu}

Hasil penimbangan produksi madu yang dipanen selama 5 minggu tercantum dalam Tabel 4. Analisis keragaman menunjukkan bahwa perlakuan berpengaruh nyata terhadap produksi madu $(\mathrm{P}<0,05)$. Produksi madu perlakuan A tidak berbeda nyata dengan perlakuan $\mathrm{C}$, namun nyata lebih tinggi dari perlakuan $\mathrm{B}$. Kisaran produksi madu A dan C (3.836,2 g dan 3.101,6 g ) masih tergolong dalam kisaran produksi madu normal menurut Sihombing (1997) yaitu 25-35 kg per tahun. Sebaliknya kisaran produksi madu perlakuan B di bawah produksi normal.

Perbedaan rataan bobot madu yang nyata pada setiap perlakuan diduga berkaitan dengan jumlah populasi di dalam sarang. Menurut Junus (2011), menjelaskan bahwa lebah ratu yang produktif dan jumlah lebah pekerja yang optimal dapat menunjang produksi anakan dan madu yang maksimal. Populasi lebah pada perlakuan A dan $\mathrm{C}$ nyata lebih besar dari perlakuan B (Tabel 6). Hal ini juga didukung oleh hasil uji korelasi yang menunjukkan korelasi positif yang sangat nyata antara populasi akhir dan produksi madu dengan nilai $r=0,88$. Penelitian ini menegaskan bahwa semakin besar populasi dalam sarang maka jumlah lebah pekerja yang bertugas mencari nektar semakin banyak sehingga produksi madunya juga semakin banyak, sebagaimana terlihat pada perlakuan A dan $\mathrm{C}$ yang menghasilkan madu lebih banyak dibandingkan pada perlakuan B yang memiliki populasi lebah paling sedikit. Selain jumlah populasi lebah, Iannuzzi (1983) menyatakan bahwa produksi madu juga dipengaruhi oleh suhu dan kelembaban dalam stup, namun suhu dalam stup dipenelitian ini tidak berbeda nyata (Tabel 3) dan tidak mempengaruhi produksi madu. Kondisi kelembaban dalam stup tercantum pada Tabel 5.

Hasil ANOVA menunjukkan bahwa luas ventilasi tidak mempengaruhi kelembaban sehingga perbedaan produksi madu tidak dipengaruhi oleh kelembaban. Kelembaban dalam penelitian ini masih dalam kisaran yang nyaman (Junior et al. 2010). Produksi madu dalam penelitian ini berkorelasi positif dengan jumlah populasi, namun tidak demikian produksi propolis. Produksi propolis dalam penelitian ini lebih dipengaruhi oleh kualitas ratu. Berdasarkan hasil uji korelasi menunjukkan bahwa produksi madu tidak nyata dengan produksi propolis $(\mathrm{r}=-0,058)$.

\section{Jumlah Populasi Lebah}

Jumlah rata-rata individu lebah setiap koloni pada awal dan akhir penelitian dapat dilihat pada Tabel 6. Jumlah koloni lebah pada awal penelitian masih dapat dianggap homogen karena perbedaannya tidak nyata. Perbedaan perlakuan mengakibatkan perbedaan yang nyata $(\mathrm{P}<0,05)$ terhadap jumlah populasi akhir. Pada akhir penelitian 
Tabel 5 Rentang kelembaban dalam stup setiap perlakuan

\begin{tabular}{lcccccc}
\hline \multicolumn{1}{c}{ Perlakuan } & \multicolumn{5}{c}{ Kelembaban dan KK (\%) } \\
\hline ventilasi & Pagi $(07.00)$ & KK & Siang (12.00) & KK & Sore $(17.00)$ & KK \\
\hline A $\left(0 \mathrm{~cm}^{2}\right)$ & $84-100$ & 0,5 & $42,9-68$ & 6,4 & $67,4-79,0$ & 0 \\
B $\left(50 \mathrm{~cm}^{2}\right)$ & $84-100$ & 0,4 & $38,7-68$ & 4,2 & $68,6-84,4$ & 0 \\
$\mathrm{C}\left(100 \mathrm{~cm}^{2}\right)$ & $84-100$ & 0,46 & $38,2-58$ & 2,1 & $70,3-78,0$ & 0 \\
\hline
\end{tabular}

Tabel 6 Populasi lebah dari koloni setiap perlakuan

\begin{tabular}{lll}
\hline \multicolumn{1}{c}{ Perlakuan } & \multicolumn{2}{c}{ Rataan bobot koloni $(\mathrm{g})$} \\
\cline { 2 - 3 } & Awal & \multicolumn{1}{c}{ Akhir } \\
\hline A (ventilasi $\left.0 \mathrm{~cm}^{2}\right)$ & $18.894,5 \pm 958,6$ & $12.065,6 \pm 1.936,7 \mathrm{a}$ \\
B (ventilasi $\left.50 \mathrm{~cm}^{2}\right)$ & $16.380,0 \pm 2050,8$ & $8.476,4 \pm 1.504,1 \mathrm{~b}$ \\
$\mathrm{C}\left(\right.$ ventilasi $\left.100 \mathrm{~cm}^{2}\right)$ & $17.467,3 \pm 1920,7$ & $10.450,8 \pm 1.772,6 \mathrm{ab}$ \\
\hline
\end{tabular}

Keterangan : $\mathrm{a}, \mathrm{b}=$ angka yang disertai huruf berbeda pada kolom yang sama menunjukkan nilai yang berbeda nyata pada taraf $5 \%$.

(setelah minggu ke 5), semua koloni pengalami penurunan populasi. Populasi pada perlakuan B nyata paling rendah dari pada perlakuan A yang memiliki populasi tertinggi. Kemungkinan penyebab penurunan jumlah populasi lebah adalah kekurangan pakan pollen (tepung sari). Sumber tanaman yang ada di sekitar lokasi lebih didominasi tanaman kaliandra yang menyediakan banyak nektar dari pada tepung sari. Tanaman ini memberikan nektar yang melimpah bagi lebah untuk dijadikan sebagai madu (Sulistyo 2006). Menurut Gojmerac (1983), sebagian besar kebutuhan total protein suatu koloni lebah madu dipenuhi dari tepung sari.

Protein sangat penting untuk pertumbuhan dan perkembangan tubuh, memperbaiki jaringan dan menjalankan fungsi tubuh lainya. Pernyataan lain menyebutkan bahwa kesehatan koloni lebah sangat tergantung oleh adanya polen. Koloni-koloni lebah tidak mampu merawat, membesarkan dan memelihara anakan tanpa adanya polen. Demikian pula halnya dengan lebah ratu tidak mampu menghasilkan telur dalam jumlah yang cukup banyak jika ketersediaan polen sangat sedikit (Gary 1992).

Analisis ragam menunjukkan populasi akhir tertinggi pada perlakuan $\mathrm{A}$ dan $\mathrm{C}$ serta terendah pada perlakuan B. Kekurangan polen pada perlakuan B dapat dijelaskan melalui korelasi antara populasi lebah dengan produksi propolis dan madu. Korelasi antara produksi propolis, madu, dan populasi lebah ditampilkan dalam Tabel 7.

Korelasi antara produksi propolis dengan madu dan populasi akhir menunjukkan korelasi yang tidak nyata. Sebaliknya, Tabel 7 menunjukkan bahwa antara produksi madu dan populasi akhir terdapat korelasi positif yang sangat nyata dan sangat kuat sebesar $r=0,88$, artinya ketika populasi lebah semakin besar maka produksi madu menjadi semakin besar. Hal ini dikarenakan pada saat jumlah koloni lebah banyak maka jumlah lebah pekerja yang mengumpulkan nektar pun menjadi semakin banyak. Tabel 6 memperlihatkan bahwa perlakuan B memiliki populasi akhir yang paling rendah namun produksi propolis sama banyak yang tidak berbeda nyata. Hal ini mengindikasikan pada perlakuan $\mathrm{B}$, lebah pekerjanya mengorbankan pencarian polen yang sangat bermanfaat bagi perkembangan koloni lebah.

Pemilihan Modifikasi Ventilasi Tutup Stup Terbaik

Tabel 8 merupakan kompilasi dari respon semua peubah serta tingkat koefisien keragaman (KK) yang diukur dalam penelitian ini. Tabel 8 memperlihatkan bahwa perlakuan A dan C memiliki keunggulan dalam jumlah produksi propolis, madu, dan jumlah populasi. Perbedaan antara perlakuan $\mathrm{A}$ dan $\mathrm{C}$ adalah pada perlakuan $\mathrm{A}$ memiliki nilai koefisien keragaman dari produksi propolis yang sangat besar, sehingga untuk aplikasi kepada peternak akan sangat merugikan dengan hasil produksi yang tidak merata. Lain halnya dengan perlakuan $\mathrm{C}$ yang memiliki produksi propolis, madu, dan jumlah populasi yang besar serta produksi yang lebih seragam dari masing-masing stup.

Perlakuan B merupakan perlakuan yang sebaiknya tidak dipilih karena menghasilkan produkstivitas yang rendah dibanding yang lainnya. Perlakuan A layak dipilih, namun dengan resiko produksi propolis yang sangat beragam. Perlakuan C merupakan perlakuan terbaik untuk dipilih karena menghasilkan produksi propolis, madu, dan jumlah populasi yang tinggi dan seragam. Guna mempertahankan jumlah propolis dan madu yang tinggi tanpa mengorbankan jumlah populasi pada perlakuan $\mathrm{C}$, peternak sebaiknya menambahkan polen yang sangat dibutuhkan oleh populasi lebah.

\section{KESIMPULAN}

Modifikasi luas ventilasi berpengaruh nyata terhadap produksi madu dan populasi, tetapi tidak berbeda nyata dengan produksi propolis. Perlakuan C merupakan perlakuan terbaik karena memiliki produksi madu, propolis dan jumlah populasi yang tinggi serta produksi yang lebih

Tabel 7 Korelasi antara produksi propolis, madu, dan populasi lebah

\begin{tabular}{|c|c|c|c|c|c|c|}
\hline & \multicolumn{2}{|c|}{ Propolis } & \multicolumn{2}{|c|}{ Madu } & \multicolumn{2}{|c|}{ Populasi akhir } \\
\hline & P-hit & $\mathrm{r}$ & P-hit & $\mathrm{r}$ & P-hit & $\mathrm{r}$ \\
\hline Propolis & - & - & 0,837 & $-0,058$ & 0,626 & 0,137 \\
\hline Madu & 0,837 & $-0,058$ & - & - & 0 & 0,881 \\
\hline Populasi akhir & 0,626 & 0,137 & 0 & 0,881 & - & - \\
\hline
\end{tabular}


Tabel 8 Kompilasi dari respon semua peubah dalam penelitian

\begin{tabular}{|c|c|c|c|c|c|c|}
\hline \multirow[t]{2}{*}{ Peubah } & \multicolumn{6}{|c|}{ Perlakuan } \\
\hline & $\mathrm{A}$ & KK & $\mathrm{B}$ & KK & $\mathrm{C}$ & KK \\
\hline Produksi Propolis & tn & - & tn & + & tn & + \\
\hline Produksi Madu & $\mathrm{a}$ & + & $\mathrm{b}$ & + & $\mathrm{a}$ & + \\
\hline Jumlah Populasi & $\mathrm{a}$ & + & $\mathrm{b}$ & + & $\mathrm{ab}$ & + \\
\hline Jumlah Terbaik & \multicolumn{2}{|c|}{$2 \mathrm{a}$ dan $2+$} & \multicolumn{2}{|c|}{$2 \mathrm{~b}$ dan $3+$} & \multicolumn{2}{|c|}{$2 \mathrm{a}$ dan $3+$} \\
\hline
\end{tabular}

Keterangan: $\mathrm{tn}=$ tidak nyata; $\mathrm{KK}=$ koefisien keragaman; Tingkat huruf, $\mathrm{a}=$ baik $\mathrm{b}=$ buruk simbol; + adalah baik dan - adalah buruk

seragam pada setiap stup. Penyusutan bobot koloni lebah terjadi pada semua koloni yang disebabkan oleh kurangnya pollen sebagai sumber pakan bagi anakan lebah.

\section{DAFTAR PUSTAKA}

Anggraini AD. 2006. Potensi propolis lebah madu Trigona spp. sebagai bahan Antibakteri. [skripsi]. Bogor (ID): Institut Pertanian Bogor. Budiaman, Rahman A. 2006. Uji efektivitas empat variasi propolis trap terhadap produksi propolis lebah madu A. mellifera L. [jurnal]. Makassar (ID): Universitas Hasannudin.

DaSilva FAA, Bueno PCP, Grego'rio LE, Silva MLA, Albuquerque S, Bastos JK. 2004. In vitro trypanocidal activity evaluation of crude extract and isolated compounds from Baccharisdracunculifolia D.C. (Asteraceae). J Pharm Pharmacol. 56, 1195D1199.

Free JB. 1982. Bees and Mankind. Oxford London and Northampton (US): Alden pr.

Gary NE. 1992. Activities and Behaviour of Honey Bee. In J M Graham (eds), The Hive and the Honey Bee. Illionis (CAN): Dadant and Sons, Hamilton pp 322328.

Giselle CORP, Angel R B , Isabel R d V T. 2009. Environmental factors influencing propolis production by the honey bee Apis mellifera in Minas Gerais State, Brazil. Journal of Apicultural Research and Bee World 48(3): 176-180 (2009). DOI 10.3896/IBRA.1.48.3.05.

Gojmerac WL. 1983. Bee, Beekeeping, Honey and Pollination. Inc Westport Connecticut (US): Avi Publishing Company.

Guerreiro De Lima M. 2005. Efeito de variáveis ambientais, rainhas selecionadas esistemas coletores na produção de própolis por abelhas africanizadas Apis mellifera (Hymenoptera, Apoidea). [PhD thesis]. Brazil (BR): Universidade Estadual Paulista, SP.

Hilario SD, Imperatriz-Fonseca VL, Kleinert A de MP. 2000. Flight activity and colony strength in the stingless bee melipona bicolor (Apidae meliponinae). Rev Bras Biol 60:299-306.

Husaeni EA. 1986. Potensi produksi nektar dari tegakan kaliandra bunga merah (Calliandra calotyrsus Meissn). Di dalam: Pembudidayaan Lebah Madu untuk Peningkatan Kesejahteraan Masyarakat. Prosiding Lokakarya; Sukabumi, 20-22 Mei 1986. Jakarta (ID) : Perum Perhutani. hlm 87-91.

Iannuzzi J. 1983. Propolis: The most mysterious hive element - part 1. American Bee Journal (AS), 1983, August, pp. 573.
Jager AJ de. 2001. The effect of increased propolis production on the productivity a honeybee farming system. [dissertation]. Departement of Agricultural Management. Port Elizabeth Technikon (tZA): Saasveld George Campus.

Jonathan, Sarwono. 2006. Metode Penelitian Kuantitatif dan Kualitatif. Yogyakarta (ID): Graha Ilmu.

Junus M. 2011. Pengaruh umur lebah ratu, jumlah sisiran eram, dan penyekat ratu terhadap pertambahan bobot anggota koloni lebah A. mellifera. Jurnal Ilmu-ilmu Peternakan 21 (3): 1-10.

Mattjik AA, Sumertajaya IM. 2002. Perancangan Percobaan dengan Aplikasi SAS dan Minitab Jilid I, Bogor (ID): IPB Pr.

Pavord AV. 1970. Bees and Beekeeping. London (GB): Cassel Ltd. Pcelovodstvo Magazine. 2012. Propolis Production In The Apiary . Oliver Mihajlovic, Penerjemah. Russia ( RU ): Riboe .

Pusat Perlebahan Apiari Pramuka. 2005. Lebah Madu, Cara Beternak dan Pemanfaatannya. Jakarta (ID): Penebar Swadaya.

Radiati LE. 2001. Pemanfaatan perekat lebah (propolis) sebagai antimikroba dan pelapis edible pada keju. [skripsi]. Bogor ( ID ): Institut Pertanian Bogor.

Rochim A, Junus M, Minarti S. 2013. Pengaruh penambahan pakan stimulan dan penyekat sisiran terhadap tingkat kesukaan lebah madu $A$. mellifera menjelang musim bunga. [jurnal]. Malang (ID): Universitas Brawijaya.

Samsudin. 2008. Virus Patogen Serangga:Bio-Insektisida Ramah Lingkungan [internet]. Diunduh [4 Juni 2014] tersedia pada: http://LembagaPertanian Sehat/ developUsefulInnovationForFamersRubrik.

Sihombing DTH. 1997. Ilmu Ternak Lebah Madu. Yogyakarta (ID) : Gadjah Mada University Pr.

Singh S. 1962. Beekeeping in India. New Delhi (IN): Indian Council of Agricultural Research.

Sulistyorini CA. 2006. Inventarisasi tanaman pakan lebah madu $A$. cerana ferb di perkebunan teh gunung mas Bogor. [skripsi]. Bogor (ID): Institut Pertanian Bogor.

Yani A, Purwanto BP. 2006. Pengaruh iklim mikro terhadap respon fisiologis sapi peranakan Fries Holland dan modifikasi lingkungan untuk meningkatkan produktivitasnya. [ulasan]. Med Petern. 29(1):35-36. 